\title{
Character Education Implementation in SMP Negeri 3 Sampit
}

\author{
Novianti Rahmawati ${ }^{1, *}$, Muhamat Qahfi ${ }^{1}$, Sasqia Anna Karina ${ }^{1}$, Alivermana \\ Wiguna $^{2,4}$, Riza Amalia ${ }^{2}$, Khairil Anwar ${ }^{2}$, Husna Mariyani ${ }^{3}$, Jayadi $^{2}$, Agus Heriyanto $^{2}$ \\ ${ }^{1}$ Economic Education Department, STKIP Muhammadiyah Sampit, Indonesia \\ ${ }^{2}$ Guidance and Counseling Department, STKIP Muhammadiyah Sampit, Indonesia \\ ${ }^{3}$ Mathematic Education Department, STKIP Muhammadiyah Sampit, Indonesia \\ ${ }^{4}$ MAN Kotawaringin Timur \\ "Corresponding author. Email: novi@ stkipmsampit.ac.id
}

\begin{abstract}
Character education has a very important role, because of various problems regarding the character of the nation's children today. The Ministry of National Education is also moving fast, declaring cultural education and national character as a national movement. Character education must be carried out by every school, one of them is in SMP Negeri 3 Sampit. This study discusses how to implement character education in SMP Negeri 3 Sampit in the 2019/2020 Academic Year. The research method used is a qualitative method, with data collection techniques using interviews and documentation. The research informants were school principals, teachers, and students of SMP Negeri 3 Sampit. The results of this study indicate that the strengthening of character education at SMPN 3 Sampit began to be well implemented, especially in terms of religious character values, nationalism, independence, cooperation, and integrity.
\end{abstract}

\section{Keywords: Character education, implementation, SMP Negeri 3 Sampit}

\section{INTRODUCTION}

Character education for some time has become a great hope of Indonesian people [1]. The need for education that can produce superior Indonesian people is felt important because moral degradation continues to occur in the younger generation [2]. Therefore, strengthening character education in the current context is very relevant to overcoming the moral crisis that is affecting the country.

Character education has a very important role because various problems regarding the character problems of the nation's children today often arise along with the changing times, such as increased violence among adolescents, the use of language and words that are not polite, abuse of narcotics, and dangerous drugs, student brawls, dishonesty in working on exam questions, and loss of respect for older people and teachers, and other phenomena of moral degradation. Therefore character education needs to get special attention from parents, schools, and government [3]. One form of government concern, President Joko Widodo has issued Presidential Regulation No. 87 of 2017 concerning Strengthening Character Education. This Presidential Regulation states that the next step to strengthen character education is the education movement under the responsibility of the education unit to strengthen the character of students through the harmonization of the process of heart, taste, thought, and sports by involving and cooperating between education units, families and communities as part of Mental Revolution National Movement [2].

The Ministry of National Education is also moving fast, declaring cultural education and national character as a national movement. Character education must be carried out by each school. Character education in this school aims to improve the quality of implementation and educational outcomes in schools that lead to the achievement of student character formation [4]. One of the schools that have implemented character education is SMP Negeri 3 Sampit. Based on the research assessment, the implementation of character education for junior high school (SMP) has been carried out in one of the junior high schools in Kotawaringin Timur district, Central Kalimantan, namely SMP Negeri 3 Sampit. The author is interested in choosing SMP Negeri 3 Sampit because the school is a model school established and fostered by the Education Quality Assurance Institute (LPMP) to become a reference school for other surrounding schools in implementing education quality assurance independently. Model schools were selected from schools that did not meet the National Education Standards to be fostered by LPMP to implement education quality assurance to be guided by five surrounding schools. The 
impacted school is hereinafter referred to as the impact school. The problem in this research: How is the implementation of character education in SMP Negeri 3 Sampit in the 2019/2020 Academic Year?

\section{METHOD}

This type of research is qualitative research, with the method of collecting data is interviews and documents. The study was conducted at the Sampit 3 Middle School (SMP) in Street of Christopel Mihing No. 69, Baamang Tengah, Baamang District, Sampit City, Kotawaringin Timur Regency. The subjects of the study were the school principal, teachers, and students of SMP Negeri 3 Sampit.

\section{RESULT AND DISCUSSION}

\subsection{Vision, Mission, and Branding of SMP Negeri 3 Sampit}

SMPN 3 Sampit has a vision: Excellent in achievement and good character based on faith, science, and technology and environmentally friendly. The mission which constitutes the steps to achieve the above vision is: Realizing quality education; Realizing a just education; Realizing education that produces graduates who are smart, skilled, competitive, having good character and virtuous character; Creating a healthy, clean, green, and beautiful school environment; and Creating transparent and accountable school management.

To realize the Vision, Mission of the school, in meetings/meetings of the service is designed and agreed to make branding that is Shining, which means Achievement, Religion, Sportsmanship, Intellectual, Asri, and Friendly. Created because the desire of all school residents to always excel by not ignoring religious values to realize intelligent students, mastering science, and technology that is noble and environmentally sound. This Character Education Strengthening Program is integrated into the formulation of vision and mission and School Curriculum documents and school branding [5].

\subsection{Purpose of Strengthening Character Education in SMP 3 Sampit}

There are several goals for Strengthening Character Education at SMPN 3 Sampit, namely: Building and equipping the Indonesian Golden Generation in 2045 to face the dynamics of change in the future with 21 st century skills; Developing a National Education platform that places character meanings and values as the sole or main generator of education implementation, taking into account the diversity of educational units in all regions of Indonesia; Restore character education as the spirit and foundation of education with harmonization of hearts (ethics), tastes (aesthetics), thought (literacy), and sports (kinesthetic) through the integration of extracurricular, co-curricular, extracurricular, and non-curricular activities; Revitalize and strengthen the capacity of the education ecosystem (principals, teachers, supervisors and school committees) to support the expansion of character education implementation; Build a network of public involvement as sources of learning inside and outside of school; Preserve the culture and identity of the Indonesian people in support of the National Movement for Mental Revolution (GNRM) [5].

\subsection{Implementasi Pendidikan character di SMPN 3 Sampit}

The results of the study are presented to determine the planting of character education in SMP 3 Sampit. This data was obtained from interviews and observations described as follows. The inculcation of character education in schools is important because this SMP Negeri 3 Sampit is a school that is located in a densely populated community with diverse cultural, economic, and parental educational backgrounds that have a variety of characters. After all, to realize students who have the character of SMP Negeri 3 Sampit apply The five main character values are priorities for strengthening character education in schools, namely:

\subsubsection{The values of religious characters}

The values of religious characters such as prayer in a congregation for Muslims and short worship for Christianity, Friday charity movements, donations, and AlQur'an literacy is carried out by way of rotation every day [6]. And the attitude of loving the environment that has been implemented in schools such as social services in the framework of commemorating Religious Holidays, maintaining school cleanliness such as making a rotating picket schedule for both teachers and students [7].

\subsubsection{Nationalist character values}

Nationalist character values that have been applied such as holding ceremonies every Monday and National Holidays, commemorating school anniversary, holding student council elections openly, row students in the field 30 minutes before the first-hour starts, led by a picket teacher, following warnings religious holidays at the nearest mosque, Then the attitude of loving the motherland that has 
been applied such as singing national and regional compulsory songs, following extracurricular activities, following flags and school rules. And the attitude of mutual respect that has been implemented in schools such as shaking hands with the teacher before entering the school gate and shaking hands with the teacher before entering class to start the lesson, greeting when the teacher enters the class .

\subsubsection{The independent character values}

The independent character values that have been applied are students taking lessons seriously, carrying out the assignments given full responsibility, making class structures, and making student class picket schedules alternately. Then the creative attitude that has been applied at school is happy to participate in various activities at school and happy to ask questions about the lessons being learned. And the attitude of the learner that has been applied at school is to do the task independently, carry out the task with full responsibility, and take lessons seriously.

\subsubsection{Character values of cooperation}

Character values of cooperation that have been implemented are cooperation after morning gymnastics on Friday, class pickets and page pickets are carried out every day in rotation. Then the attitude of cooperation that has been implemented at school is cooperation after morning gymnastics on Friday, and carrying out picketing alternately and the attitude of deliberation that has been applied is to create a class structure together, make student council organizers together, deliberation in the distribution of ceremonial officers and deliberations in the distribution of duty pickets.

\subsubsection{The integrity character values}

The integrity character values that have been applied are obeying school rules, respecting friends' opinions, and courtesy to teachers, school staff, and fellow friends. Then the attitude of honesty that has been applied is honest in doing the tasks that have been given, it is not too late to come to school and dare to ask if you feel you do not understand in learning. And the exemplary attitude that has been applied at school is not being late to school, being responsible for carrying out tasks, not violating school rules, happy to help troubled friends in kindness, and happy working in the school [8].

Based on the results of observations and interviews conducted by the authors from various sources above, it can be concluded that SMP Negeri 3 Sampit in character education, has applied the five character values accordingly. This is by the opinion of Fitratunnisa (2015: 103) Character education is an effort made by the teacher as a system of inculcating character values to students about God, self, others and with the environment (family environment, community, and school environment) manifested in positive attitudes, words, and behavior. This is also consistent with the research conducted by Wiwik Wijayanti. The results of the study concluded that the implementation of character education in SMP Negeri 1 and MTS Al-Qasimiyah carried out 18 character values to students namely: religious, honest, tolerance, discipline, hard work, creative, independent, democratic, curiosity, national spirit, love of the motherland, respect for achievement, friendly/communicative, peace-loving, fond of reading, caring for the environment, caring socially, responsibly, through being integrated into subjects, self-development, school culture, extracurricular activities, and daily activities at home and the community [9].

\section{CONCLUSION}

This study concludes that SMP Negeri 3 Sampit in character education, has begun to implement strengthening of character education, specifically in the following five characters; religion, nationalism, independence, cooperation, and integrity. It is hoped that over time, the reinforcement of embedded character education continues to grow.

\section{REFERENCES}

[1] R. Maya, "Esensi Guru Dalam Visi-Misi Pendidikan Karakter," Edukasi Islami : Jurnal Pendidikan Islam, Pp. 281-296, 2013.

[2] Zulfarno, Mursal, And R. Saputra, "Aktualisasi Pendidikan Karakter Dalam Pembelajaran AlIslam Dan Kemuhammadiyahan Di Sma Muhammadiyah Kota Padang," Ruhama: Islamic Education Journal, Vol. 1, No. 2, Pp. 117-131, 2019.

[3] A. S. R. Baidarus, Tasman Hamami, Fitriah M. Suud, "Al-Islam Dan Kemuhammadiyahan Sebagai Basis Pendidikan Karakter". AlAsasiyya: Journal Basic Of Education, Vol. 4, No. 1, Pp. 71-91, 2019, [Online]. Available: Http://Journal.Umpo.Ac.Id/Index.Php/AlAsasiyya/Index. 
[4] Handayani, Puspita, "Pendidikan Karakter Matakuliah Al-Islam Dan Kemuhammadiyahan (Aik-1) Terhadap Perilaku Mahasiswa Fakultas Ekonomi dan Bisnis Umsida,” Pp. 296-309.

[5] S. P. Daniati, S. Subiyantoro, And S. S. Fadhilah, "Natural School Culture As A Free And Fun Alternative Education In Building The Students' Character," Elementary Education Online, Vol. 18, No. 1, Pp. 331-342, 2019, Doi: 10.17051/Ilkonline.2019.527617.

[6] I. Mawardi, "Signifikansi Sunnah Nabi Dalam Kurikulum Pembinaan Kepribadian Anak (Perspektif Psikologi Pendidikan Islam)," Tarbiyatuna, Vol. 6, No. 2, Pp. 77-90, 2015.

[7] T. Saswandi And A. P. Sari, "Analisis Penerapan Nilai-Nilai Al Islam Dan Kemuhammadiyahan Dalam Perkuliahan," Jurnal Educatio: Jurnal Pendidikan Indonesia, Vol. 5, No. 1, P. 27, 2019, Doi: $10.29210 / 120192327$.

[8] M. Ali, S. A. Kuntoro, And S. Sutrisno, "Pendidikan Berkemajuan: Refleksi Praksis Pendidikan K.H. Ahmad Dahlan,” Jurnal Pembangunan Pendidikan: Fondasi Dan Aplikasi, Vol. 4, No. 1, P. 43, 2016, Doi: 10.21831/Jppfa.V4i1.7821.

[9] A. Wiguna, Isu-Isu Kontemporer Pendidikan Islam. Deepublish, Yogyakarta, 2015. 